\title{
Coastal water environment suitability studies for green mussel cultivation in Pasaran Island, Lampung Bay
}

\author{
Arief Wicaksono, Wahyu Lazuardi, Ariani Puji Astuti, Tika \\ Maitela, Andiyanti Putri Estigade, et al.
}

Arief Wicaksono, Wahyu Lazuardi, Ariani Puji Astuti, Tika Maitela, Andiyanti Putri Estigade, Muhammad Hilmy Aziz, Dea Nadia, Mousafi Dimas, Pramaditya Wicaksono, Wirastuti Widyatmanti, "Coastal water environment suitability studies for green mussel cultivation in Pasaran Island, Lampung Bay," Proc. SPIE 11311, Sixth Geoinformation Science Symposium, 113110D (21 November 2019); doi: 10.1117/12.2548485

SPIE Event: Sixth Geoinformation Science Symposium, 2019, Yogyakarta, Indonesia 


\title{
Coastal Water Environment Suitability Studies for Green Mussel Cultivation in Pasaran Island, Lampung Bay
}

\author{
Arief Wicaksono, Wahyu Lazuardi, Ariani Puji Astuti, Tika Maitela, Andiyanti Putri Estigade, Muhammad \\ Hilmy Aziz, Dea Nadia, Mousafi Dimas, Pramaditya Wicaksono, Wirastuti Widyatmanti \\ Faculty of Geography, Universitas Gadjah Mada, Sekip Utara Jalan Kaliurang, Bulaksumur, Yogyakarta, \\ 55281 \\ wicaksono.ariefo8@gmail.com
}

\begin{abstract}
The green mussel cultivation by fishermen in Pasaran Island is influenced by nature and uses simple technology without regarding water conditions. In fact, site selection considering the water condition is one of the important factors in determining the success of quality green mussel cultivation. High market demand but not supported by modern technology, good marketing strategies, price stability, and appropriate cultivation site can reduce the production of green mussels. This research was conducted to determine the optimal location for the green mussel cultivation around Pasaran Island, in Lampung Bay and to formulate a management strategy based on the map. Modeling parameters measured on the field include depth, salinity, $\mathrm{pH}$, temperature, current velocity, dissolved oxygen, water clarity, and chlorophyll-a. Data processing methods include inverse distance weighted (IDW) interpolations and fuzzy overlay. The study result in the form of raster-based physical water suitability maps for green mussel cultivation are intended to refine the uncertainties in the vector-based data presentation on water quality data so that it is expected to provide additional information to avoid a less optimal cultivation environment so it maintain the quality of green mussel products and support to accelerate aquaculture production raising program (minapolitan) in Lampung Bay.
\end{abstract}

Keywords: physical water suitability, fuzzy overlay, management, Pasaran Island, Lampung Bay

\section{INTRODUCTION}

Green mussels live in estuary waters, mangroves and bay areas with muddy sand substrates and medium salt concentration. Green mussels cultivation is fairly easy because it can survive and breed at high environmental pressures and without feeding [1]. Green mussels can be useful as a biofilter or filter organism that can improve environmental quality. Ysebaert et al. [2] have proven that the cultivation has very small or even no impact on the decline in environmental quality. However, aquaculture products can have a negative impact on human health [3], if the cultivation activities are carried out in areas contaminated with household waste and the amount of red tide. This is because mollusk obtains food by filtering the water column (filterfeeders) so the pollutants can accumulate in the body of the cultivation biota. To avoid this problem, an initial step that must be conducted is water feasibility study.

Green mussel fishermans have their own uniqueness, the uniqueness is that the number of fishermen is the most compared to other types of fishermen and other jobs [4], because green mussels are high economic value aquatic commodities. The types of nurseries on Pasaran Island by green mussel fishermens are natural nurseries. Green mussel cultivation by fishermen on Pasaran Island is influenced by nature. The high demand 
for green mussels on the market every year, according to an initial interview with one green mussel fishermens on Pasaran Island, is a distinct advantage for green mussel fishermens on the Pasaran Island. However, the need for green mussel still cannot be fulfilled because fishermen still rely on fishing from nature. The low income of fishermen is caused by various problems such as [4], the inability to utilize technology due to the relatively low level of education of fishermen, low sale of green mussel, the unstable price of green mussel and also the existing location of green mussel cultivation influence green mussel production.

Regarding the socio-economic conditions of green mussel fishermen on Pasaran Island, this has been investigated by [4] with the following findings. 1) The fishery-owned cage location on the Pasaran Island is quite suitable, located at a depth of 1-3 m;2) The size of green mussel cultivation cage owned by fishermen on Pasaran Island is medium, which is between $4 \times 4 \mathrm{~m}^{2}-9 \times 9 \mathrm{~m}^{2}$; 3) The seeding activities of green mussel carried out by fishermen on Pasaran Island are natural hatcheries originating from nature, and green mussel harvesting is in good quality harvest, which shell diameter when harvested is about from 6-8 cm; and 4) Marketing carried out by fishermen on Pasaran Island is by selling to the place of fish auction.

Green mussel cultivation must adapt to the environmental conditions around it to avoid adverse environmental conditions, such as current, weather and contamination levels. Green mussel cultivation location must meet technical requirements in supporting business sustainability and production targets. In addition, it considers non-technical factors, namely the acceptance of local residents and local village officials to cultivate green mussels to avoid social conflict [1]. The success of green mussel cultivation must be supported by ideal environmental conditions so that aquaculture activities carried out are environmentally sound and sustainable [5], [6]. To ensure that environmental conditions can support the cultivation of green mussels, an analysis of water suitability is an initial stage that must be conducted. The success of green mussel cultivation depends on the availability of natural seeds, the ideal condition of the aquatic environment so that it can support the growth of aquaculture biota, and low predators or diseases [7]. In this study, the analysis focus is more on the conditions of aquatic environment that influence the growth of green mussels. This study aims to determine the optimal location for green mussel cultivation around Pasaran Island, Teluk Betung Barat District, Bandar Lampung City (Figure 1).

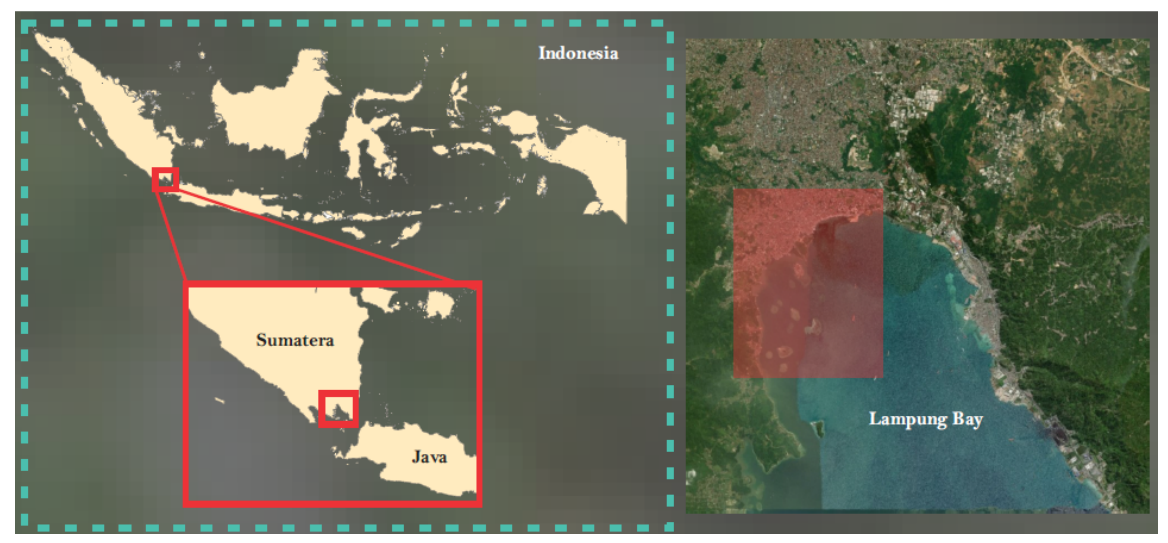

Figure 1. Study Area.

\section{RESEARCH METHOD}

Various methods were developed to create site suitability maps for green mussel cultivation. In addition, the parameters considered in model making also vary. Several studies related to determining the optimal location for green mussel cultivation using physical, biological and chemical parameters such as salinity [8], [9], [10], pH [10], sea surface temperature [9], [11], [10], water clarity [8], [10], current velocity [8], [10], 
water depth [8], [9], [11], [10], dissolved oxygen [9], [10], seabed substrate [11], [10], chlorophyll [8], [11], [10], tides [8], and pollution levels [8].

The phenomena boundaries at the earth's surface can be clearly distinguished (crisp) or fuzzy. The water condition is one example of the earth's surface phenomenon whose boundaries are not crisp but it change gradually. Therefore, the representation of spatial data into GIS needs to be adjusted to the nature of the phenomenon. Meanwhile, spatial data structures are grouped into two types, namely vector and raster data. In vector data, objects are described in the form of points, lines, and polygon, whereas in raster data, objects are described as pixels (grid), where each pixel has a certain value. The selection of vector and raster spatial data structures is adjusted according to the research objectives and analysis unit used.

From some related literature, this study consider salinity, $\mathrm{pH}$, sea surface temperature, water clarity, current velocity, depth, dissolved oxygen, and chlorophyll as input data in modeling. All of these parameters were obtained in the field on April 29, 2017. The tools used in the study included GPS for plotting sample locations, $\mathrm{pH}$ meters for measuring $\mathrm{pH}$, secchi disks for measuring water clarity, refractometers for measuring salinity, current meters to measure current velocity, digital thermometers for measuring sea surface temperatures (SST), portable depthmates for measuring water depth, and sample bottles for taking water samples. Laboratory tests for water quality in the form of dissolved oxygen (DO) and chlorophyll were carried out in the Water Quality Laboratory of Lampung Marine Aquaculture Center (BBPBL). Data is processed using ArcGIS 10.5 software. The suitability map for green mussel cultivation was obtained based on the research of Ali et al. (2015) with modifications, with parameter scores presented in Table 1.

Table 1. Suitability Parameter Score for Green Mussel Cultivation.

\begin{tabular}{ccccccccccc}
\hline $\begin{array}{c}\text { Water } \\
\text { Quality } \\
\text { Parameter }\end{array}$ & 10 & 9 & 8 & 7 & 6 & 5 & 4 & 3 & 2 & 1 \\
\hline $\begin{array}{c}\text { Salinity } \\
\text { (ppt) }\end{array}$ & $27-32$ & $25-33$ & $24-34$ & $23-35$ & $18-36$ & $15-40$ & $12-45$ & $10-50$ & $5-55$ & $0-65$ \\
pH & $7.9-8.2$ & $7.8-8.3$ & $7.7-8.4$ & $7.6-8.5$ & $7.5-8.6$ & $7.4-8.7$ & $7.3-8.8$ & $7.0-8.9$ & $6.9-9.0$ & $6.8-9.1$ \\
$\begin{array}{c}\text { SST }\left({ }^{\circ} \mathrm{C}\right) \\
\text { water } \\
\text { clarity }\end{array}$ & $26-32$ & $25-33$ & $24-34$ & $23-35$ & $22-36$ & $21-37$ & $20-38$ & $19-39$ & $18-40$ & $17-41$ \\
$\begin{array}{c}\text { (cm) } \\
\text { current }\end{array}$ & $22-25$ & $21-26$ & $19-30$ & $17-35$ & $15-40$ & $13-45$ & $12-50$ & $10-55$ & $8-60$ & $7-65$ \\
$\begin{array}{c}\text { velocity } \\
\text { (m/sec) }\end{array}$ & $1-3$ & $1.5-3.5$ & $2-4$ & $2.5-4.5$ & $3-5$ & $3.5-6$ & $4-7$ & $6-9$ & $10-15$ & 15 \\
$\begin{array}{c}\text { water } \\
\text { depth (m) }\end{array}$ & $>8$ & 8 & 7 & 6 & 5 & 4 & 3 & 2 & - & 1 \\
$\begin{array}{c}\text { DO (mg) } \\
\text { chlorophyll } \\
\left(\mathrm{mg} / \mathrm{m}^{3}\right)\end{array}$ & $>8$ & $7-6$ & $6-5$ & $5-4$ & $4-3$ & - & - & $3-2$ & $2-1$ & - \\
\hline
\end{tabular}

Source: [10] with modifications

Data from field measurements and laboratory tests are then interpolated using the Inverse Distance Weighted (IDW) method because according to [12], the IDW method is more appropriate for interpolating physical data in coastal areas because it does not produce values that exceed the sampled data. The population in this study were waters on some of the Lampung Bay Market Island with an area of 1,154.43 ha. There are 32 sample points of field measurement, which is distributed follows Figure 2, determined by systematic sampling. The systematic sampling method was chosen because it was able to reduce the potential for bias in selecting samples and being representative of the population, assuming no data was lost. 


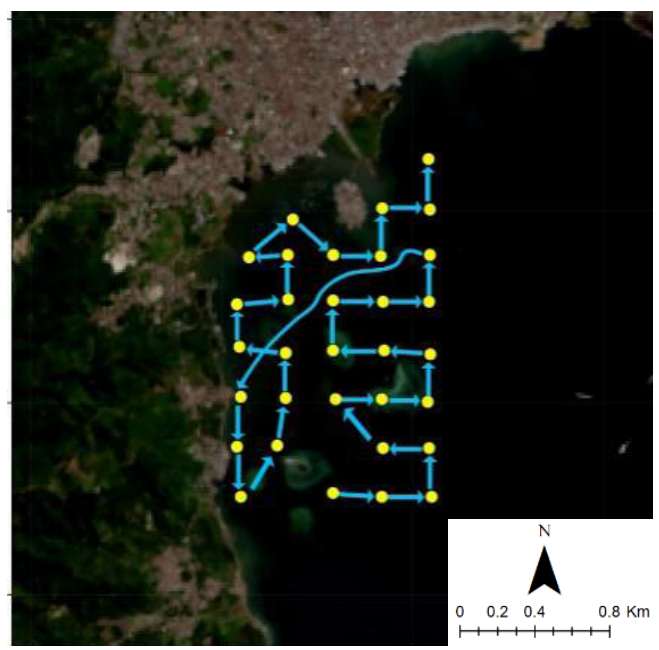

Figure 2. Sample Distribution

The interpolated field data are then normalized so that they have value range from $0-1$. The eight parameters are then fuzzy overlaid using sum operations, as illustrated in Figure 3, to produce a green mussel cultivation suitability map. The final result map also has a value range from $0-1$ and is then classified into four suitability classes as shown in Table 2.

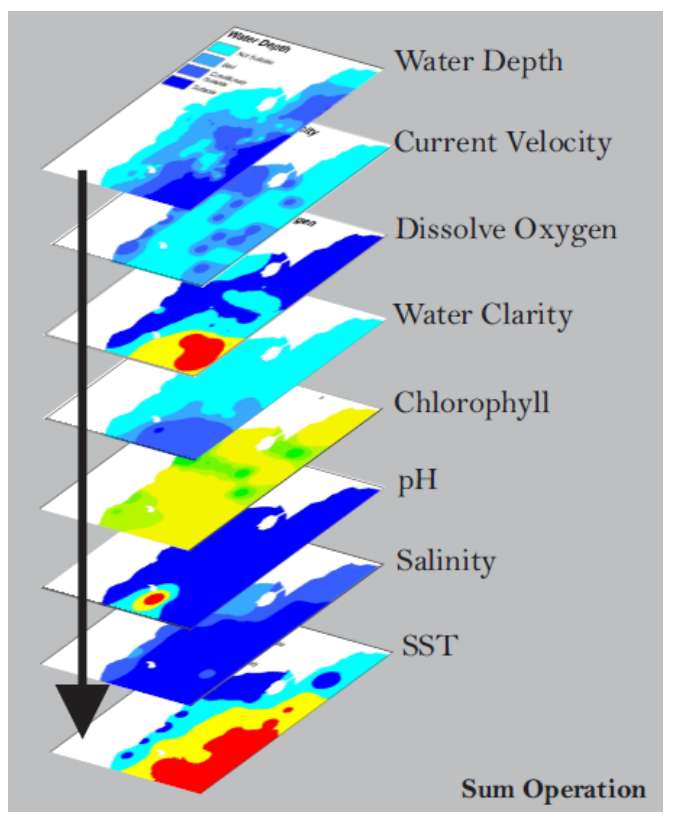

Figure 3. Fuzzy Overlay Using Sum Operator 
Table 2. Site Suitability Categories for Green Shellfish Cultivation

\begin{tabular}{ccc}
\hline Score Category & Water Evaluation & Description \\
\hline $0.1-0.25$ & Not Suitable & $\begin{array}{c}\text { The location cannot be used for the cultivation and } \\
\text { cannot support the life of green mussels } \\
\text { The location supports the life of green mussels but } \\
\text { cannot be used for cultivation }\end{array}$ \\
$0.26-0.50$ & Bad & $\begin{array}{c}\text { The location can be used for cultivation and supports } \\
\text { the life of green mussels }\end{array}$ \\
$0.51-0.75$ & Conditionally Suitable & $\begin{array}{c}\text { Strongly supports the life of green mussels and is } \\
\text { recommended for cultivation }\end{array}$ \\
\hline
\end{tabular}

Source: [10] with modifications

\section{RESULT AND DISCUSSION}

The main factor that need to be considered to make green mussel cultivation runs well and has high productivity, it is necessary to manage water quality to maintain sustainability and ecological balance through planning in choosing the right cultivation location. The site selection plan considers the characteristics of the aquatic environment that are spatially suitable (Figure 4). The environmental characteristics are salinity, dissolve oxygen (DO), water depth, $\mathrm{pH}$, chlorophyll, sea surface temperature, water clarity, and current velocity. The results of field data collection show that the salinity of the study area has a range of values of 28 to $32 \mathrm{ppt}$, which has a low value in waters close to the coast, especially on one of the cape in the northwest, and has an increased salinity in deep waters. Having a depth of about 0.2 to 21 meters, areas close to the coast tend to be shallow compared to locations far from the coastal land whose waters are deeper. It has a DO value with a value of 4 in the southern part of study area and increases to $6.9 \mathrm{mg}$ in the northern part with a value of \pm 4 $\mathrm{mg}$. The $\mathrm{pH}$ value ranges from 4 to 8 and is quite homogeneous in the whole area, except in the southern part close to the small island, where the $\mathrm{pH}$ level of the surrounding waters is affected by marine activities that take place around the area. Chlorophyll 0.002 to $0.25 \mathrm{mg} / \mathrm{m}^{3}$ whose distribution is not too varied. The temperature is not significantly different, which is around 30 to $31^{\circ} \mathrm{C}$, where deep waters tend to be cooler than the shallow waters near the coast. Has a gradual clarity and its distribution is similar to the water depth, the water clarity value in the study waters is about 0.5 to 7 meters. The current velocity parameters are very small, which are 0.1 to $0.2 \mathrm{~m} / \mathrm{s}$. Each parameter has a fairly unique distribution form, where there are rounded patterns in several parts of the region. This pattern is caused by the interpolation algorithm used, namely IDW. IDW is an interpolation algorithm that produces interpolation by maintaining the value of the sample used. 

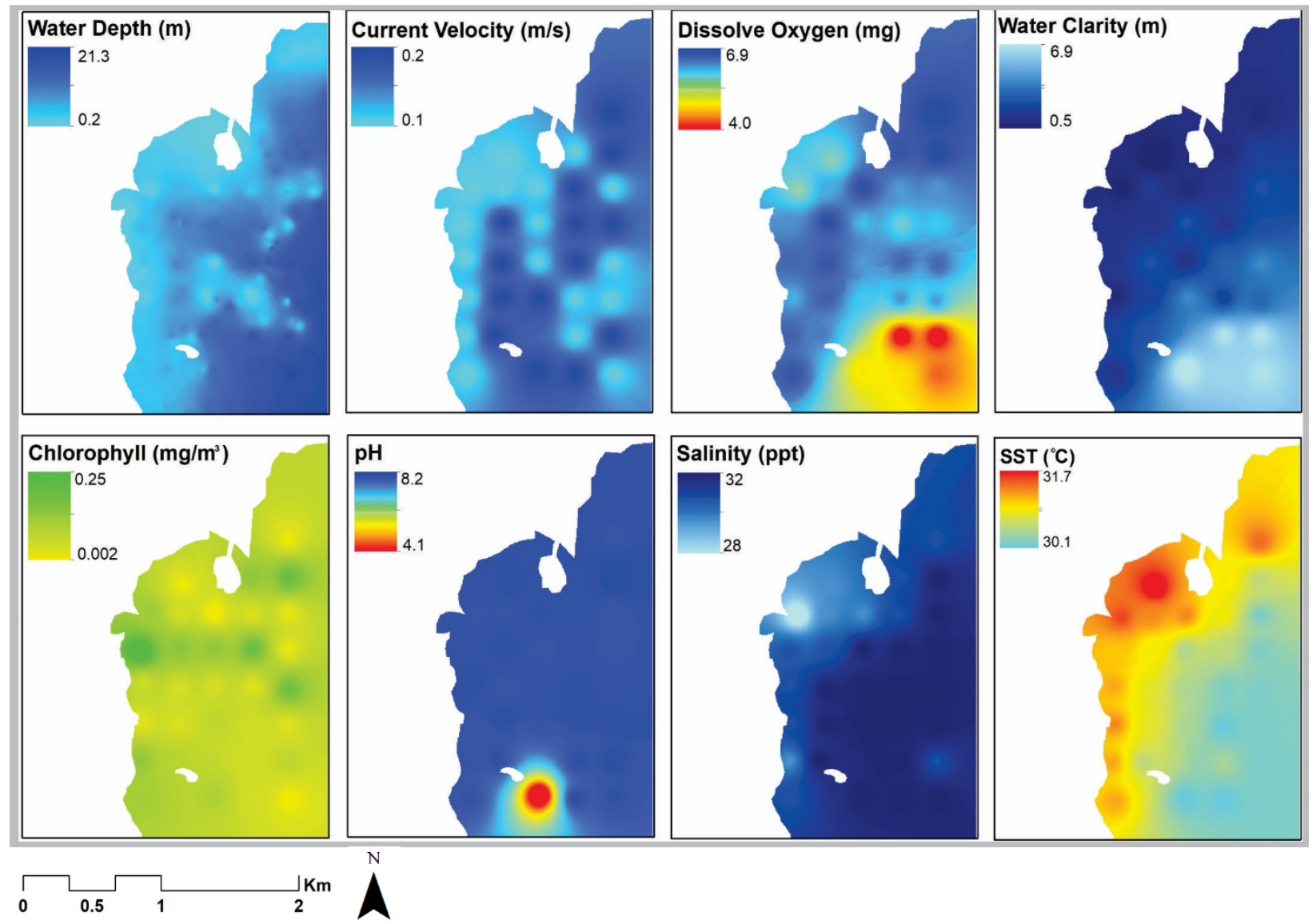

Figure 4. Water Quality Parameters Map.

The results of the site suitability map for green mussel cultivation (Figure 5) show that only a small proportion of locations are considered suitable, and most of them are not suitable waters. Locations that have suitable categories are in waters that are quite far from the coastal land area, in rather deep waters, and good water clarity. If reviewed from the overall water quality parameters, the brightness and depth parameters of the water are parameters that have a dominant influence on the spatial distribution of locations according to the results.

Locations with not suitable categories are spread almost to fill the entire study area. This causes the closest parts to the coast and built land areas that have poor water quality for aquaculture activities. This quality is due to the large amount of waste in the built-up area whose output is headed for marine waters, causing the surrounding waters to be polluted. The pollution certainly does not only affect one physical aspect of water quality, but almost completely. Other locations located far from the coast and the quality of the waters are not suitable for green mussel cultivation due to the influence of ship activities and local ports. where the fuel spill is one of the factors that causes the quality of the surrounding waters to be bad. 


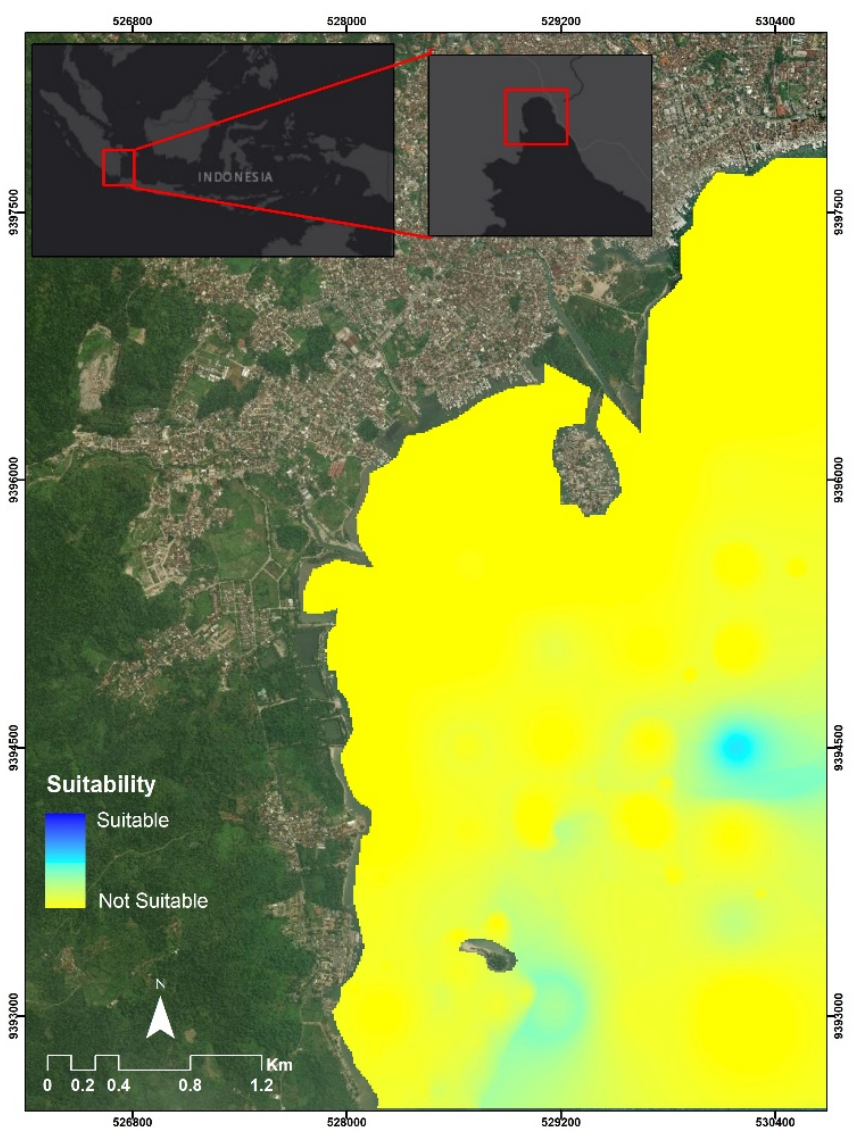

Figure 5. Green Mussel Cultivation Site Suitability Map.

If reviewed from the water quality parameters used, the current velocity becomes one of the data whose value is very low and it can be said to be not suitable for cultivation activities. Slow current velocity can cause more easily deposited material to contaminate the green mussels and even cause death for aquaculture products. Moreover, water clarity is also one parameter that is able to represent the quality of the aquatic environment. Waters with very low clarity explain that the aquatic environment has many suspended sediments which is an accumulation from various sources, where it is one indication of the poor condition of the aquatic environment.

In contrast to good water conditions, where the clarity of certain water depths is still clear without any form of suspended sediments that is seen as an indication of a good and healthy aquatic environment. Depth parameters are also one of the factors that cause many locations that are not suitable for green mussel cultivation. The majority of the waters that are close to built-up land and coastal areas have shallow depths, where green mussel cultivation is not good if it is conducted in shallow waters. Based on the water quality standard for green mussel cultivation, the ideal water depth for cultivation activities is above 8 meters. DO values in the southern part of the waters also do not support the cultivation of green mussel, because the results of field measurements show DO values in these waters are around $4 \mathrm{mg}$, which is based on the character quality of green mussel aquaculture, the value is still below $8 \mathrm{mg}$ (very suitable), differ from the northern waters of the study area where the DO value is $6.9 \mathrm{mg}$, where the value is close to the suitable value for green mussel cultivation. If the location is still forced on aquaculture activities, many negative impacts can occur. Among of them are aquaculture activities become less productive, aquaculture products become dangerous if consumed by people because it has lived and developed in polluted waters, loss of operational costs, and so on. 


\section{CONCLUSION}

Based on the suitability map, the optimal location for green mussel cultivation around Pasaran Island is only a small part of the entire study area, and most of them are not suitable. Locations that have suitable categories are in waters that are quite far from the coastal land area, in rather deep waters, and good water clarity (east and south of study area). If reviewed from the overall water quality parameters, the brightness and depth parameters of the water are parameters that have a dominant influence on the spatial distribution of locations according to the results.

The feasibility analysis of the water in this study can be sharpened through several stages, namely: adding criteria / factors that affect the growth and survival of green mussels (for example source of seed, wave height, water fertility) and socio-economic conditions or supporting infrastructure; and pay attention to the quality and quantity of data used in the analysis so that better results can be obtained. In addition, it is necessary to involve the community and users (stakeholders) in the planning and decision-making processes so that the implementation of the field of aquaculture activities carried out can be sustainable [13].

\section{REFERENCES}

[1] WWF-Indonesia. 2015. Budidaya Kerang Hijau (Perna Viridis). Jakarta Selatan: WWF-Indonesia.

[2] Ysebaert, T., Hart, M., \& Herman, P.M.J. 2009. Impacts of bottom and suspended cultures of mussels Mytilus spp. on the surrounding sedimentary environment and macrobenthic biodiversity. Helgoland Marine Research, 63: 59-74.

[3] Chinabut, S., Somsiri, T., Limsuwan, C., \& Lewis, S. 2006. Problems associated with shellfish farming. Rev. sci. tech. Off. int. Epiz., 25: 627-635.

[4] Ferdinan, Dimas. 2016. Kondisi Sosial Ekonomi Nelayan Kerang Hijau di Pulau Pasaran Tahun 2016. Skripsi. Bandar Lampung: Fakultas Keguruan dan Ilmu Pendidikan Universitas Lampung.

[5] Costa-Pierce, B. 2008. An ecosystem approach to marine aquaculture: a global review. In D. Soto, J. AguilarManjarrez, and N. Hishamunda (Eds.). Building an ecosystem approach to aquaculture. FAO Fisheries and Aquaculture Proceedings. No. 14. Rome, FAO, p. 81-155.

[6] FAO. 2010. Aquaculture development. 4. Ecosystem approach to aquaculture. FAO Technical Guidelines for Responsible Fisheries. No. 5, Suppl. 4. Rome, FAO, 53 pp.

[7] Vakily, J.M. 1989. The biology and culture of mussels of the genus Perna. ICLARM Studies and Review 17, 63 pp.

[8] Kepmen Lingkungan Hidup No. 51 Tahun 2004 tentang baku mutu air laut.

[9] Radiarta, I.N., Saputra, A., dan Ardi, I. 2011. Analisis Spasial Kelayakan Lahan Budidaya Kerang Hijau (Perna Viridis) Berdasarkan Kondisi Lingkungan di Kabupaten Cirebon, Jawa Barat. J. Ris. Akuakultur, 6(2), pp. 341-352.

[10] Ali, M., Maharani, H.W., Hudaidah, S., dan Fornando, H. 2015. Analisis Kesesuaian Lahan di Perairan Pulau Pasaran Provinsi Lampung untuk Budidaya Kerang Hijau (Perna Viridis). Maspari Journal, 7(2), pp. 57-64.

[11] Wisnawa, I.G.Y. 2013. Studi Pemetaan Kesesuaian Budidaya Kerang Hijau (Perna Viridis) Menggunakan Data Citra Satelit dan SIG di Perairan Laut Tejakula. Jurnal Sains dan Teknologi, 2(2), pp. 239-243.

[12] Radiarta, I. N., Saputra, A., Haryadi, J., Johan, O., \& Prihadi, T. H. (2006). Pemilihan Lokasi Budidaya Ikan dalam Keramba Jaring Apung Menggunakan Analisis Multi Kriteria dan Sistem Informasi Geografis di Teluk Kapontori, Sulawesi Tenggara. Jurnal Riset Akuakultur, 1(3), 337-348

[13] Stead, S.M., Burnell, G., Goulletquer, P. 2002. Aquaculture and its role in integrated coastal zone management. Aquaculture International. 10: 447-468. 